\title{
判読カード解説 Explanation of Aerial Stereogram
}

青山墓地

Aoyama Cemetry

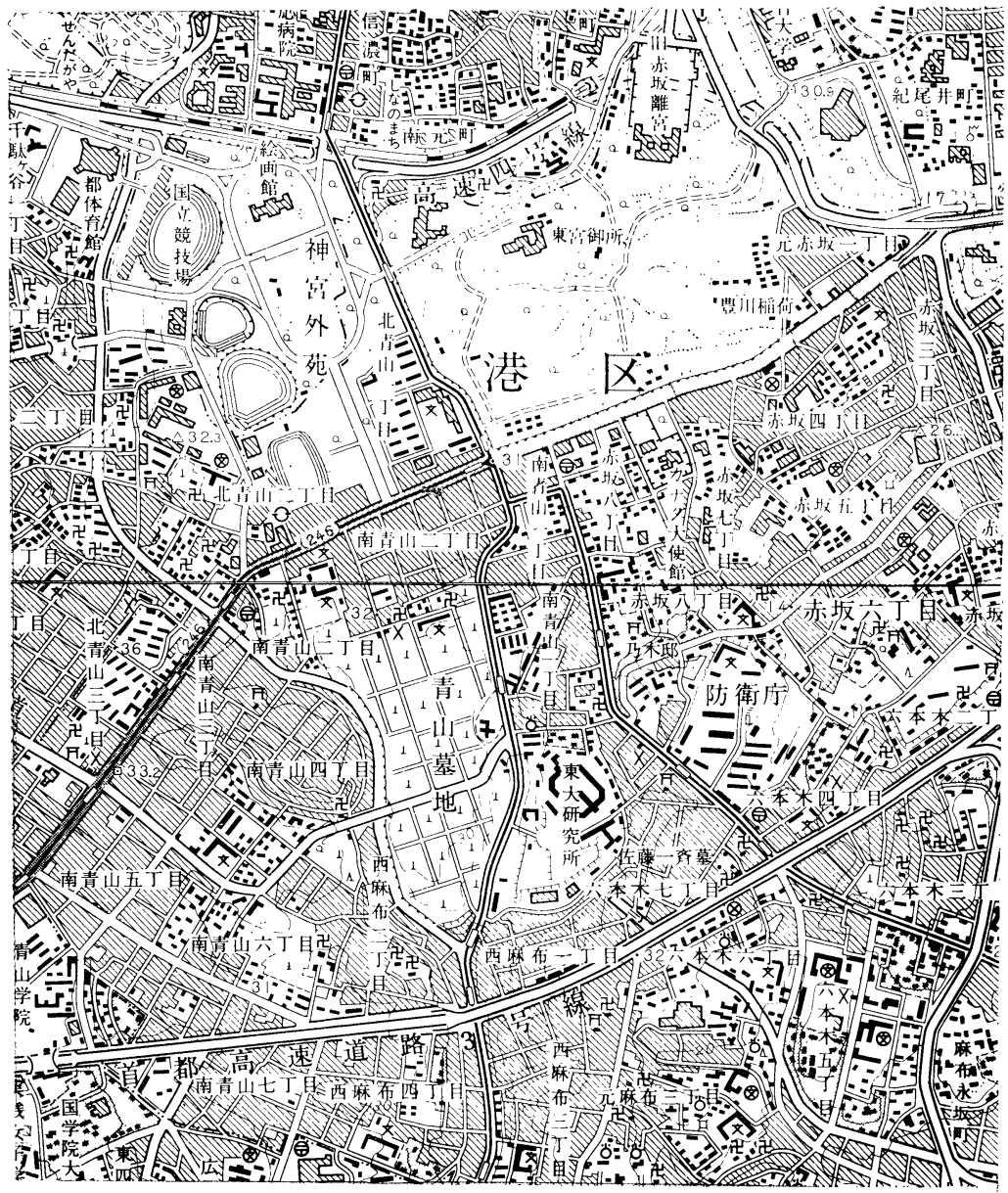

青山墓地は，東京都港区に㚣り，写真で見られるように，高台上执よびその縁辺の斜面にわたってひろがって いる。

この附近は，江戸時代には武家屋敷のあったところでこの墓地は明治 5 年に設けられた。

国道 246 号をはさんで北側には明治神宮外苑があり，絵唹館，神宮球場，国立競技場などが空中写真上で見ら れる。神宮外苑の東側の部分はると紀州侯の邸地であったとこつである。旧赤坂離宮, 東宮御所などが写真上で 見られる。

（細井将右・庄司浩）

Aoyama Cemetry is on the upland in the central part of Tokyo. It was constructed in 1870s after Meiji Restauration. 
解説 Explanation of Aerial Stereogram

鳴門 の塩 田

Salt field in Naruto

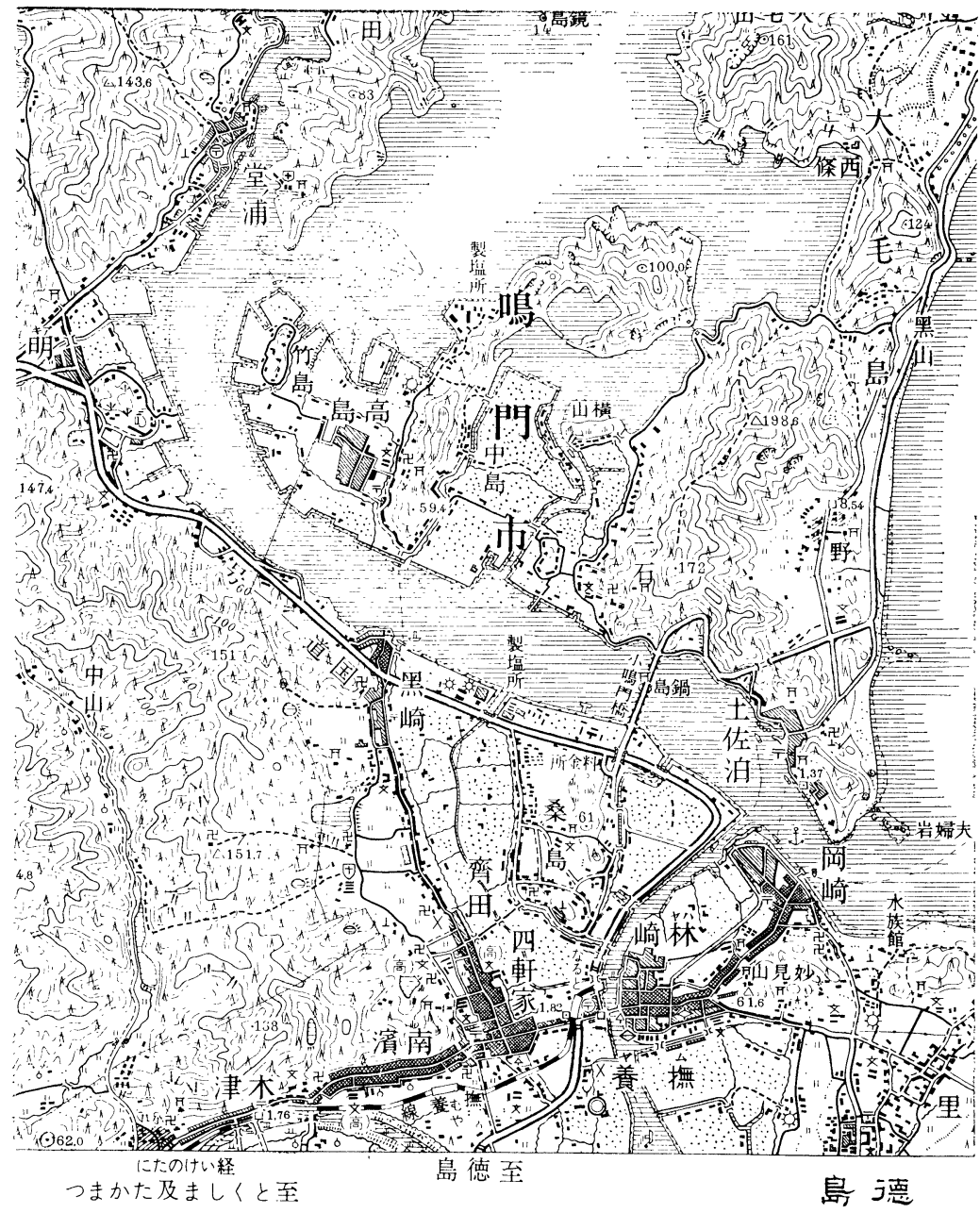

徳血県鳴門市撫養にある塩田である。慶長 4 年に藩主蜂須賀家政により，入浜式塩田が開かれた。本地域は降 雨の少い瀬戸内式気候の延長地域であり，製塩業の発達を見た。従来は塩田の砂上に海水を撒いて水分を蒸発さ せる入浜式塩田であったが, 戦後, 枝条架流下中に蒸発させる流架式塩田に切り換えら机, 写真上でハーモニカ 状の枝条架が多く見られる。濃縮水は真空式の製塩工場に送られ，低い気圧で沸点を下げて製塩が行なわれてい る。

（細 井 将右・山崎 正躬）

Salt field in Naruto, eastern coast of Shikoku Is. In this region, the first salt field was opened in 1599. Because of its little precipitation, the coastal area of the Setonaikai sea is the most producing district of salt in Japn. 